\title{
Performance Analysis of GCC Banks: A Survey
}

\author{
Manuel Fernandez ${ }^{1}$, Luluwa Juma ${ }^{1}$, Hanan Alkharoossi ${ }^{1} \&$ Robinson Joseph ${ }^{1}$ \\ ${ }^{1}$ School of Business, Skyline University College, Sharjah, UAE \\ Correspondence: Manuel Fernandez, School of Business, Skyline University College, PO Box 1797, University City \\ of Sharjah, Sharjah, UAE. E-mail: mfernandez@ skylineuniversity.ac.ae
}

Received: November 8, 2020

Accepted: December 20, 2020

Online Published: January 25, 2021

doi:10.5430/ijfr.v12n1p357

URL: https://doi.org/10.5430/ijfr.v12n1p357

\begin{abstract}
The banking sector plays an essential economic role in providing financial intermediation and economic acceleration by converting deposits into productive investments. A strong banking sector can deal with any crisis and contribute abundantly to the stabilization of the economy. GCC is home to one of the fastest increasing banking sectors in the world. The objective of this study is to identify the country that has the best-performing banking sector in the GCC and to rank the best-performing banks in the GCC based on different parameters like the total asset, net profit, return on asset (ROA), return on equity (ROE), capital adequacy ratio and cost-to-income ratio. The study includes all the 55 listed banks from the GCC countries. The study revealed that Emirates NBD from the UAE is at the top rank under Net Profit and ROE, the second rank in ROA, and the third rank in Total Assets. Qatar National Bank from Qatar has been ranked the best under the category Total Assets, rank two under net profit, rank four in ROE, and cost-to-income ratio. The National Commercial Bank from Saudi Arabia was ranked third in ROE and ROA and rank four under Total Asset and Net Profit.
\end{abstract}

Keywords: performance, total asset, net profit, return on asset, return on equity, capital adequacy ratio, cost-to-income ratio

\section{Introduction}

The banking industry is one of the main pillars of the economic system and plays an indispensable role in the nations' economic growth. Banks boost economic growth by mobilizing savings and channelizing it to productive industries. A strong banking sector can deal with any crisis and contribute abundantly to the stabilization of the economy.

The Gulf Cooperation Council (GCC) is an oil-based region with the largest proven crude oil reserves in the world (486.8 billion barrels), representing 35.7\% of the world's total. The six countries of the GCC region, namely Bahrain, Kuwait, Oman, Qatar, Saudi Arabia, and the United Arab Emirates, have enjoyed a spectacular economic boom until late 2008. The GCC economy tripled in size to $\$ 1.1$ trillion from 2002 to 2008. For the GCC region, the oil and gas sector represents approximately $73 \%$ of total export earnings and roughly $63 \%$ of the government's revenues. The region is continuing its economic reform programs, focusing on attracting domestic, regional, and foreign private sector investments into various sectors like oil and gas, power generation, telecommunications, and real-estates (Joseph \& Fernandez, 2016). Nevertheless, the recent downward slide in the oil price has slowed the pace of investment and development projects in the region's economic activities. The predictions are that the oil price will continue to be low, which compels them to look for other revenue sources for growth and development. In this situation, the banking sector's role becomes more relevant as they can mobilize the required resources for development. Table 1 presents the economic data on debt and gross domestic product (GDP) for each of the GCC nations for 2019. 
Table 1. Economic data on debt and GDP for GCC countries for the year 2019

\begin{tabular}{lcccccc}
\hline Country & Bahrain & Kuwait & Oman & Qatar & UAE & $\begin{array}{c}\text { Saudi } \\
\text { Arabia }\end{array}$ \\
\hline Debt & & & & & & \\
\hline Public debt (\% of GDP)* & 101.7 & 15.2 & 59.9 & 53.2 & 20.1 & 23.2 \\
\hline External debt (\% of GDP)* & 192.9 & 46.5 & 105.6 & 107.6 & 72.6 & 30.4 \\
\hline GDP & & & & & & \\
\hline GDP (US\$ billion)** & 38.2 & 137.6 & 76.6 & 191.8 & 405.8 & 779.3 \\
\hline GDP growth (\%)** & 1.8 & 0.7 & 0.5 & 0.1 & 1.3 & 0.3 \\
\hline
\end{tabular}

Source: Compiled from *Bloomberg; **IMF: World Economic Outlook

GCC is home to one of the fastest increasing banking sectors in the world. Over the past decade, the GCC banking industry has experienced steady growth and stability and is quite sound and well-equipped to withstand any shocks. The GCC banking sector plays a significant role in promoting the gross domestic product and operates as an engine to enhance the GCC's economic growth.

The financial technology disruption has impacted the banking sector heavily, compelling them to adjust their outlook, the way they go about with the daily operations, and how they compact the ever-increasing competition from the domestic operators and international players from the banking and non-banking sectors. The regulators are also facilitating the required changes through reformative policies and regulations. The banking sector's effective functioning is one of the most important goals of economic reforms in GCC countries.

The exponential technological advancements, digitalization, and economic uncertainties have severely impacted the banking sector's profitability, efficiency, and growth. Moreover, there is a new wave of competition from the new entrants from the non-banking sector, providing various financial services at very competitive rates. This study's main objective is to identify the country with the best performing banking sector in the GCC and identify the best performing banks in the GCC.

The remainder of the paper is structured as follows. Section 2 presented a brief review of the literature on banking. Section 3 described the methodology. Section 4 focused on analysis and discussions. Finally, our conclusions are presented in Section 5.

\section{Literature Review}

A considerable number of empirical studies have been conducted in the banking sectors of developed countries. However, the studies relating to the Middle East region are not many, and a majority of these studies concentrate on evaluating the performance of commercial banks in comparison to Islamic banks.

Bank performance gives a clear picture of banks' economic success in a certain period of bank activities to generate profits effectively and efficiently (Ayanda, Christoper \& Mudhasiru, 2013). It is crucial to assess the performance of a bank from period to period and compare it with peers in the industry and even with peers in the neighboring nations to ascertain whether the performance is good or bad and take measures accordingly to improve by adopting the best practices in the industry. According to Zainuddin, Wancik, Rahman, Hartati, and Rahman (2017), profitability is an indicator of bank performance. Profitability is the ability to run the bank's performance to earn profits from year to year (Menicucci \& Paolucci, 2016).

One of the bank profitability measurements is the return on assets (ROA), taking into account banks' ability to earn over all assets (Lipunga, 2014). ROA is the most straightforward measure of bank profitability. ROA is a bank's ability to generate income by the optimal utilization of all assets. ROA shows the effective and efficient use of company assets to create profits (Kingu, Macha, \& Gwahula, 2018). It reflects the capability of a bank to generate profits from its asset management functions. Hence it is frequently used as a critical ratio for evaluation of bank profitability in the studies according to Molyneux and Thornton (1992), Claessens and Laeven (2004), and Mamatzakis and Bermpei (2016). Haidary and Abbey (2018) opined that ROA evaluates returns based on the entire base of bank assets, including capital invested by the owner and customer deposits.

Many studies suggest a positive relationship between bank size and profitability (Flamini et al., 2009; Athanasoglou, Brissimis \& Delis, 2008; Molyneux \& Thornton, 1992; Bourke, 1989; Short, 1979). Their studies show that size is 
associated with economies of scale, and banks become more profitable as they become larger. Moreover, banks with greater size can raise capital at a lower cost, and thus they appear to be more profitable (Bikker \& $\mathrm{Hu}, 2002$; Goddard et al., 2004; Short, 1979).

Operational expense is also important as it is often considered an indicator of administrative efficiency. Studies have repeatedly reported a significant negative relationship between bank profitability and operating costs (Athanasoglou et al., 2008; Molyneux \& Thornton, 1992; Bourke, 1989) based on the argument that cost eats away profit and is negatively related to performance. Banks with a high cost to income ratio are likely to report low profits and signal management inefficiency with adverse consequences for profitability (Pasiouras \& Kosmidou, 2007). Zopounidis and Kosmidou (2008) examined the determinants of performance of Greek commercial banks during the period 1990-2002 and found that profitability is positively associated with well-capitalized banks and lower cost to income ratios.

The capital adequacy ratio (CAR) is a crucial measure of the sustainability of a bank. CAR provides guarantees and convenience to bank depositors, serves as security for customer deposits, and helps smooth operations. The ratio works by comparing total capital with total assets. Total capital only includes ordinary shares, money invested by owners, and bank-related reserves (Usman \& Lestari, 2019). CAR shows the proportional balance of assets in the bank between owners and depositors (Haidary \& Abbey, 2018). Capital adequacy is an indicator to determine the financial health of banks. The bank's capital adequacy can determine whether the bank has sufficient resources to bear unexpected losses in the future (Aspal \& Dhawan, 2014). Several studies discussed the relationship between CAR and profitability. Haidary and Abbey (2018) and Eljelly (2013) found a positive influence between capital adequacy and ROA - the higher the capital, the higher will be the level of public trust in their savings. Ani, W.U. et al. (2012) studied the determinants of commercial bank's profitability in Nigeria for ten years from 2001 to 2010 . The study concluded that bank size does not boost the profits of any commercial banks in Nigeria, whereas the better capital-asset ratio improves bank profitability.

A peep is made into a few of the studies carried out in the GCC. Daly and Frikha (2017) used Data Envelopment Analysis (DEA) to examine the determinants of banking performance in Bahrain between 2005 and 2009. The performance was analyzed through a comparative study of 12 banks - six conventional and six Islamic banks focusing on return on assets (ROA), return on equity (ROE), and efficiency, and concluded that the increase in the size of Islamic banks and the rapid growth in the customers' deposits are the important factors of performance. Hassan al-Tamimi (2010) analyzed UAE banks' performance from 1996 to 2008 and observed that conventional banks' performance is affected by liquidity and concentration, while for Islamic, the number of branches and costs are the most significant factors.

The studies in the GCC are very few and are limited in scope as they are either country-specific or confined to comparing the conventional banks with the Islamic banks. This study proposes overcoming at least a few of these limitations as the study encompasses all the listed banks in the GCC and is from a holistic perspective.

\section{Research Methodology}

This study's main objective is to identify which country has the best performing banking sector from among the GCC countries and bring to light the best performing banks in the GCC based on different performance parameters. The different parameters used to rank the bank performances are total asset, net profit, return on asset (ROA), return on equity (ROE), capital adequacy ratio, and cost-to-income ratio. This study is based solely on secondary data collected from the official websites and reports of the Centrals banks of each GCC country, official websites and annual reports of the listed banks, and various publications of the statistical departments, governments, and the press. The study covers a period of three years, from 2017 to 2019 . The study includes all the 55 listed banks from the GCC countries. The sample data have been collected for three years, from 2017 to 2019. Banks-specific variables are hand-collected from the bank's official websites and annual reports. The collected data are tabulated and analyzed using appropriate analytical tools.

\section{Analysis and Discussions}

It is felt appropriate to conduct a country-wise analysis first and then go deeper into each country and analyze the performance of each bank operating in the GCC. The country-wise data are given in Tables 2 to 4 for the period 2017 to 2019 . 
Table 2. Total assets and net profits of GCC banks - country-wise

\begin{tabular}{lrrrrrr}
\hline GCC Countries & \multicolumn{3}{c}{ Total assets (US\$ billion) } & \multicolumn{3}{c}{ Net profit (US\$ million) } \\
\cline { 2 - 7 } & $\mathbf{2 0 1 7}$ & $\mathbf{2 0 1 8}$ & $\mathbf{2 0 1 9}$ & $\mathbf{2 0 1 7}$ & $\mathbf{2 0 1 8}$ & $\mathbf{2 0 1 9}$ \\
\hline Bahrain & 95.1 & 96.1 & 104.6 & $1,060.7$ & $1,248.5$ & $1,267.6$ \\
\hline Kuwait & 251.9 & 264.5 & 286.3 & $2,722.1$ & $3,247.7$ & $3,218.8$ \\
\hline Oman & 71.0 & 76.2 & 79.4 & 884.1 & 986.9 & 940.7 \\
\hline Qatar & 395.8 & 408.4 & 446.4 & $5,851.1$ & $6,410.5$ & $6,760.5$ \\
\hline Saudi Arabia & 592.5 & 582.6 & 652.0 & $11,982.0$ & $8,542.5$ & $12,033.0$ \\
\hline UAE & 578.4 & 606.2 & 724.6 & $9,836.2$ & $10,771.1$ & $12,273.0$ \\
\hline Total & $1,984.7$ & $2,034.0$ & $2,293.3$ & $32,336.2$ & $31,207.2$ & $36,493.6$ \\
\hline
\end{tabular}

Source: Compiled from websites of various Central banks in the GCC

The total assets across all GCC countries are showing a robust growth throughout the period of study and have increased from US $\$ 2,034$ billion in 2018 to US $\$ 2,293$ billion in 2019, a growth of $12.8 \%$ year-on-year. Similarly, the GCC banks' overall net profit has shown a remarkable growth of $16.9 \%$ year-on-year over 2018.

Table 3. Capital adequacy ratio and cost-to-income ratio of GCC banks - country-wise

\begin{tabular}{lllllll}
\hline \multirow{2}{*}{ GCC Countries } & \multicolumn{3}{c}{ Capital adequacy ratio } & \multicolumn{3}{c}{ Cost-to-income ratio } \\
\cline { 2 - 7 } & $\mathbf{2 0 1 7}$ & $\mathbf{2 0 1 8}$ & $\mathbf{2 0 1 9}$ & $\mathbf{2 0 1 7}$ & $\mathbf{2 0 1 8}$ & $\mathbf{2 0 1 9}$ \\
\hline Bahrain & $20.3 \%$ & $19.4 \%$ & $19.7 \%$ & $50.7 \%$ & $50.5 \%$ & $53.4 \%$ \\
\hline Kuwait & $18.4 \%$ & $18.3 \%$ & $18.0 \%$ & $39.7 \%$ & $37.9 \%$ & $39.5 \%$ \\
\hline Oman & $16.9 \%$ & $17.0 \%$ & $17.1 \%$ & $59.0 \%$ & $53.2 \%$ & $54.1 \%$ \\
\hline Qatar & $17.1 \%$ & $17.6 \%$ & $18.5 \%$ & $29.5 \%$ & $28.1 \%$ & $26.6 \%$ \\
\hline Saudi Arabia & $20.2 \%$ & $20.5 \%$ & $19.6 \%$ & $38.6 \%$ & $38.5 \%$ & $38.5 \%$ \\
\hline UAE & $18.7 \%$ & $17.0 \%$ & $17.6 \%$ & $36.2 \%$ & $37.2 \%$ & $36.5 \%$ \\
\hline Average & $18.7 \%$ & $18.4 \%$ & $18.5 \%$ & $41.7 \%$ & $40.5 \%$ & $41.0 \%$ \\
\hline
\end{tabular}

Source: Compiled from data from websites of various Central banks in the GCC

During 2019, the capital adequacy ratio has shown a very nominal increase of $0.1 \%$ over 2018 but is well above the minimum regulatory requirements. The overall cost-to-income ratio increased marginally by $0.5 \%$ in 2019 .

Table 4. ROE and ROA of GCC banks - country-wise

\begin{tabular}{lllllll}
\hline GCC Countries & \multicolumn{3}{l}{ Return on equity (ROE) } & \multicolumn{3}{c}{ Return on assets (ROA) } \\
\hline & $\mathbf{2 0 1 7}$ & $\mathbf{2 0 1 8}$ & $\mathbf{2 0 1 9}$ & $\mathbf{2 0 1 7}$ & $\mathbf{2 0 1 8}$ & $\mathbf{2 0 1 9}$ \\
\hline Bahrain & $5.8 \%$ & $7.6 \%$ & $6.3 \%$ & $0.9 \%$ & $1.1 \%$ & $0.8 \%$ \\
\hline Kuwait & $9.2 \%$ & $10.4 \%$ & $9.0 \%$ & $1.0 \%$ & $1.2 \%$ & $1.0 \%$ \\
\hline Oman & $6.6 \%$ & $8.4 \%$ & $6.6 \%$ & $0.9 \%$ & $1.1 \%$ & $0.9 \%$ \\
\hline Qatar & $12.0 \%$ & $13.0 \%$ & $13.2 \%$ & $1.4 \%$ & $1.5 \%$ & $1.5 \%$ \\
\hline Saudi Arabia & $12.2 \%$ & $8.9 \%$ & $11.5 \%$ & $1.8 \%$ & $1.4 \%$ & $1.7 \%$ \\
\hline UAE & $13.5 \%$ & $14.3 \%$ & $13.9 \%$ & $1.7 \%$ & $1.8 \%$ & $1.7 \%$ \\
\hline Total & $10.2 \%$ & $10.5 \%$ & $10.3 \%$ & $1.3 \%$ & $1.3 \%$ & $1.3 \%$ \\
\hline
\end{tabular}

Source: Compiled from data from websites of various Central banks in the GCC 
The overall ROE decreased marginally by $0.2 \%$ in 2019 , whereas the ROA has remained the same at $1.3 \%$ throughout the period of study. Further analysis was carried out to find the top-performing banks based on different parameters, starting with total assets. Table 5 ranks the best five banks in the GCC based on the total assets.

Table 5. Top five banks in terms of total assets

\begin{tabular}{cllrr}
\hline Rank & Total Assets (US\$ Billion) & Country & Dec. 2019 & \multicolumn{1}{c}{ YoY } \\
\hline 1 & Qatar National Bank & Qatar & 259.5 & $9.57 \%$ \\
\hline 2 & First Abu Dhabi Bank & UAE & 223.8 & $10.50 \%$ \\
\hline 3 & Emirates NBD & UAE & 186.0 & $36.57 \%$ \\
\hline 4 & The National Commercial Bank & Saudi Arabia & 135.3 & $12.12 \%$ \\
\hline 5 & Abu Dhabi Commercial Bank & UAE & 110.3 & $44.78 \%$ \\
\hline
\end{tabular}

Source: Compiled and ranked by the authors

In terms of total assets, Qatar National Bank tops the rank with US\$259.5 billion. The second, third, and fifth are from the UAE, namely First Abu Dhabi Bank, Emirates NBD, and Abu Dhabi Commercial Bank. In fourth place is the National Commercial Bank from Saudi Arabia. In 2019, total assets' growth was highest for the Abu Dhabi Commercial Bank at $44.78 \%$, followed by Emirates NBD at 36.57\%. Table 6 ranks the best five banks in the GCC based on the net profits.

Table 6. Top five banks in terms of net profit

\begin{tabular}{cllrr}
\hline Rank & Net Profit (US\$ Million) & Country & Dec. 2019 & \multicolumn{1}{c}{ YoY } \\
\hline 1 & Emirates NBD & UAE & $3,947.90$ & $44.44 \%$ \\
\hline 2 & Qatar National Bank & Qatar & $3,942.50$ & $4.08 \%$ \\
\hline 3 & First Abu Dhabi Bank & UAE & $3,408.20$ & $4.24 \%$ \\
\hline 4 & The National Commercial Bank & Saudi Arabia & $3,040.40$ & $18.77 \%$ \\
\hline 5 & Al Rajhi Bank & Saudi Arabia & $2,708.90$ & $169.46 \%$ \\
\hline
\end{tabular}

Source: Compiled and ranked by the authors

The top slot for the highest net profit in the GCC is for Emirates NBD from the UAE with a profit of US $\$ 3,948$ million, followed very closely by Qatar National Bank. The third rank is for First Abu Dhabi Bank from the UAE, and the fourth and fifth position is for the National Commercial Bank and Al Rajhi Bank, respectively, both from Saudi Arabia. Among the top five banks, the highest growth in net profit for the year 2019 is for the Saudi bank Al Rajhi Bank with an eye-popping 169.46\%. The second-highest growth in net profit is for Emirates NBD with $44.44 \%$. The third is for the National Commercial Bank from Saudi Arabia, with an appreciable increase of $18.77 \%$. Table 7 ranks the best five banks in the GCC based on ROE.

Table 7. Top five banks in terms of return on equity

\begin{tabular}{cllrr}
\hline Rank & \multicolumn{1}{c}{ Return on Equity (\%) } & Country & Dec. 2019 & \multicolumn{1}{c}{ YoY } \\
\hline 1 & Emirates NBD & UAE & $21.80 \%$ & $20.44 \%$ \\
\hline 2 & Al Rajhi Bank & Saudi Arabia & $20.40 \%$ & $183.33 \%$ \\
\hline 3 & The National Commercial Bank & Saudi Arabia & $19.10 \%$ & $13.02 \%$ \\
\hline 4 & Qatar National Bank & Qatar & $19.00 \%$ & $-3.06 \%$ \\
\hline 5 & Dubai Islamic Bank & UAE & $18.40 \%$ & $-11.54 \%$ \\
\hline
\end{tabular}

Source: Compiled and ranked by the authors 
The topmost rank for the highest ROE in the GCC is for Emirates NBD from the UAE with $21.80 \%$, followed very closely by Al Rajhi Bank with 20.40\%, the National Commercial Bank with 19.10\%, Qatar National Bank with 19\%, and Dubai Islamic Bank with $18.40 \%$. The Al Rajhi Bank from Saudi Arabia exhibited a remarkable increase of $183.33 \%$ over 2018. Table 8 ranks the best five banks in the GCC based on ROA.

Table 8. Top five banks in terms of return on asset

\begin{tabular}{cllrr}
\hline Rank & \multicolumn{1}{c}{ Return on Asset (\%) } & Country & Dec. 2019 & \multicolumn{1}{c}{ YoY } \\
\hline 1 & Al Rajhi Bank & Saudi Arabia & $2.70 \%$ & $145.45 \%$ \\
\hline 2 & Emirates NBD & UAE & $2.50 \%$ & $19.05 \%$ \\
\hline 3 & The National Commercial Bank & Saudi Arabia & $2.40 \%$ & $14.29 \%$ \\
\hline 4 & National Bank of Bahrain & Bahrain & $2.30 \%$ & $4.55 \%$ \\
\hline 5 & Riyad Bank & Saudi Arabia & $2.30 \%$ & $64.29 \%$ \\
\hline
\end{tabular}

Source: Compiled and ranked by the authors

The ROA is only marginally different among the top five. Al Rajhi Bank tops the list with $2.70 \%$, followed by Emirates NBD with 2.50\%, the National Commercial Bank with 2.40\%. National Bank of Bahrain and Riyad Bank with $2.30 \%$ each. The Al Rajhi Bank from Saudi Arabia exhibited an increase of $145.45 \%$ over 2018, the increase exhibited by Riyad Bank from Saudi Arabia is also very appreciable at 64.29\%. Table 9 ranks the best five banks in the GCC based on Capital Adequacy Ratio.

Table 9. Top five banks in terms of capital adequacy ratio

\begin{tabular}{cllcr}
\hline Rank & Capital Adequacy Ratio & Country & Dec. 2019 & YoY \\
\hline 1 & National Bank of Bahrain & Bahrain & $37.30 \%$ & $10.36 \%$ \\
\hline 2 & Bank Al Jazira & Saudi Arabia & $24.60 \%$ & $-10.55 \%$ \\
\hline 3 & Sharjah Islamic Bank & UAE & $22.80 \%$ & $28.81 \%$ \\
\hline 4 & Bank of Bahrain and Kuwait & Bahrain & $21.70 \%$ & $10.71 \%$ \\
\hline 5 & SAMBA & Saudi Arabia & $21.10 \%$ & $-7.05 \%$ \\
\hline
\end{tabular}

Source: Compiled and ranked by the authors

The National Bank of Bahrain tops the list with $37.30 \%$, which far ahead of all others. Bank Al Jazira from Saudi Arabia ranks second with $24.60 \%$, followed by Sharjah Islamic Bank from the UAE with $22.80 \%$. Bank of Bahrain and Kuwait from Bahrain is at the fourth rank with $21.70 \%$, and the fifth position is for SAMBA from Saudi Arabia with $21.10 \%$. Further analysis on the improvement made during 2019 portrays that Sharjah Islamic Bank from the UAE exhibited the most significant improvement in the CAR with $28.81 \%$ year-on-year, the next highest increase is shown by Bank of Bahrain and Kuwait from Bahrain with an improvement of $10.71 \%$, followed by National Bank of Bahrain with $10.36 \%$. Table 10 ranks the best five banks in the GCC based on the cost-to-income ratio.

Table 10. Top five banks in terms of cost-to-income ratio

\begin{tabular}{clccc}
\hline Rank & \multicolumn{1}{c}{ Cost-to-income Ratio } & Country & Dec. 2019 & YoY \\
\hline 1 & Masraf Al Rayan & Qatar & $22.80 \%$ & $-5.00 \%$ \\
\hline 2 & Qatar Islamic Bank & Qatar & $22.80 \%$ & $-10.24 \%$ \\
\hline 3 & Qatar International Islamic Bank & Qatar & $24.10 \%$ & $-3.21 \%$ \\
\hline 4 & Qatar National Bank & Qatar & $26.10 \%$ & $-1.88 \%$ \\
\hline 5 & Dubai Islamic Bank & UAE & $26.70 \%$ & $-11.30 \%$ \\
\hline
\end{tabular}

Source: Compiled and ranked by the authors 
The banks from Qatar seemed to be the most efficient under this category, the top four ranks are Qatari banks, with Masraf Al Rayan and Qatar Islamic Bank at the top of the list with 22.80\%, followed by Qatar International Islamic Bank, and then the Qatar National Bank. The fifth position is for Dubai Islamic Bank from the UAE with 26.7\%, but it was observed to be the most successful in reducing their cost by $11.30 \%$ year-on-year. Table 11 gives a summary of ranking based on all the parameters.

Table 11. Ranking summary

\begin{tabular}{|c|c|c|c|c|c|c|}
\hline 气ั & Total Assets & Net Profit & ROE & ROA & CAR & $\begin{array}{c}\text { Cost-to-income } \\
\text { Ratio }\end{array}$ \\
\hline 1 & $\begin{array}{ll}\text { Qatar National } \\
\text { Bank }\end{array}$ & Emirates NBD & Emirates NBD & Al Rajhi Bank & $\begin{array}{l}\text { National Bank } \\
\text { of Bahrain }\end{array}$ & Ması \\
\hline 2 & $\begin{array}{l}\text { First Abu Dhabi } \\
\text { Bank }\end{array}$ & $\begin{array}{ll}\text { Qatar National } \\
\text { Bank }\end{array}$ & Al Rajhi Bank & Emirates NBD & Bank Al Jazira & $\begin{array}{ll}\text { Qatar } & \text { Islamic } \\
\text { Bank } & \end{array}$ \\
\hline 3 & Emirates NBD & $\begin{array}{l}\text { First Abu Dhabi } \\
\text { Bank }\end{array}$ & $\begin{array}{l}\text { The National } \\
\text { Commercial } \\
\text { Bank }\end{array}$ & $\begin{array}{l}\text { The National } \\
\text { Commercial } \\
\text { Bank }\end{array}$ & $\begin{array}{l}\text { Sharjah } \\
\text { Islamic Bank }\end{array}$ & $\begin{array}{l}\text { Qatar } \\
\text { International } \\
\text { Islamic Bank }\end{array}$ \\
\hline 4 & $\begin{array}{l}\text { The National } \\
\text { Commercial } \\
\text { Bank }\end{array}$ & $\begin{array}{l}\text { The National } \\
\text { Commercial } \\
\text { Bank }\end{array}$ & $\begin{array}{ll}\text { Qatar National } \\
\text { Bank }\end{array}$ & $\begin{array}{l}\text { National Bank } \\
\text { of Bahrain }\end{array}$ & $\begin{array}{lr}\text { Bank of } \\
\text { Bahrain and } \\
\text { Kuwait }\end{array}$ & $\begin{array}{ll}\text { Qatar National } \\
\text { Bank }\end{array}$ \\
\hline 5 & $\begin{array}{l}\text { Abu Dhabi } \\
\text { Commercial } \\
\text { Bank }\end{array}$ & Al Rajhi Bank & $\begin{array}{l}\text { Dubai Islamic } \\
\text { Bank }\end{array}$ & Riyad Bank & SAMBA & $\begin{array}{l}\text { Dubai } \\
\text { Bank }\end{array}$ \\
\hline
\end{tabular}

Source: Compiled and ranked by the authors

\section{Conclusion}

A considerable number of studies have been conducted in the banking sectors of developed countries. In contrast, studies relating to the GCC are very few, and most of them are confined to evaluating the performance of commercial banks in comparison to Islamic banks. Hence it was felt significant to conduct a study to evaluate the performance of the banks operating in the GCC from a holistic perspective. Thus this study was carried out including all the listed banks in the GCC with the objective to identify the country that has the best-performing banking sector and to bring to light the best performing banks in the GCC based on different performance parameters like the total asset, net profit, ROA, ROE, capital adequacy ratio, and cost-to-income ratio. The study provides better insights for decision-makers, policymakers, and regulators. The findings of the study will help the banking customers and investors to decide which bank is the most suitable for them judiciously. It will also serve as an eye-opener for the management of these banks to take necessary measures to enhance their performance and thus improve their competitive position in the GCC banking landscape. Similarly, the policymakers and regulators may formulate policies and regulations appropriate for the betterment of the banking sector in their country and pave the way for boosting banks' performance.

In the overall analysis, it was observed that different banks are good under different parameters. The performance of three of the banks is highlighted as they come in the first four ranks in four of the parameters. The best one is Emirates NBD from the UAE, with the top rank under Net Profit and ROE, the second rank in ROA, and the third rank in Total Assets. The next best is the Qatar National Bank from Qatar, which has been ranked the best under the category Total Assets, the second-best under net profit, the fourth in ROE, and the cost-to-income ratio. The next is the National Commercial Bank from Saudi Arabia, ranked third in ROE and ROA and ranked four under Total Asset and Net Profit. It is noteworthy that most of the GCC listed banks are adopting the global best practices to enhance their performance year after year.

The limitations of this study are that it is limited to only the listed bank in the GCC, is limited to a period of three years, and the impact of current Novel Coronavirus COVID-19 is not factored into the study, as it is still an ongoing pandemic. Hence, future studies on banks may be carried out on all banks in the GCC for a more extended period 
and factor in the impact of the COVID-19 pandemic as it has disrupted all the existing systems extensively. It is believed that the post-pandemic era will never be the same as before; it will be a new normal.

\section{References}

Ani, W. U., Ugwunta, D. O., Ezeudu, I. J., \& Ugwuanyi, G. O. (2012). An empirical assessment of the determinants of bank profitability in Nigeria: Bank characteristics panel evidence. Journal of Accounting and Taxation, 4(3), $38-43$.

Aspal, P. K., \& Dhawan, S. (2014). Financial performance assessment of banking sector in India: A case study of old private sector banks. The Business \& Management Review, 5(3), 196-211.

Athanasoglou, P. P., Brissimis, S. N., \& Delis, M. D. (2008). Bank-specific, industry-specific and macroeconomic determinants of bank profitability. Journal of International Financial Markets, Institutions and Money, 18(2), 121-136.

Ayanda, A. M., Christopher, E. I., \& Mudashiru, M. A. (2013). Determinants of banks' profitability in a developing economy: Evidence from Nigerian banking industry. Interdisciplinary Journal of Contemporary Research in Business, 4(9), 155-181.

Bikker, J. A., \& Hu, H. (2002). Cyclical patterns in profits, provisioning and lending of banks and procyclicality of the new Basel capital requirements. PSL Quarterly Review, 55(221).

Bourke, P. (1989). Concentration and other determinants of bank profitability in Europe, North America and Australia. Journal of Banking \& Finance, 13(1), 65-79.

Claessens, S., \& Laeven, L. (2004). What drives bank competition? Some international evidence. Journal of Money, Credit and Banking, 36(3), 563-583.

Daly, S., \& Frikha, M. (2017). Determinants of bank performance: comparative study between conventional and Islamic banking in Bahrain. Journal of the Knowledge Economy, 8(2), 471-488.

Eljelly, A. M. (2013). Internal and external determinants of profitability of Islamic banks in Sudan: evidence from panel data. Afro-Asian Journal of Finance and Accounting, 3(3), 222-240.

Flamini, V., McDonald, C. A., \& Schumacher, L. B. (2009). The determinants of commercial bank profitability in Sub-Saharan Africa. IMF Working Papers, 1-30.

Goddard, J., Molyneux, P., \& Wilson, J. O. (2004). The profitability of European banks: a cross-sectional and dynamic panel analysis. The Manchester School, 72(3), 363-381.

Haidary, Q., \& Abbey, B. (2018). Financial Performance of Commercial Banks in Afghanistan. International Journal of Economics and Financial Issues, 8(1), 242-249.

Hassan Al-Tamimi, H. A. (2010). Factors influencing performance of the UAE Islamic and conventional national banks. Global Journal of Business Research, 4(2), 1-9.

Joseph, R., \& Fernandez, M. (2016). Growth of Stock Market in the UAE through Merger: A Comparative Study of GCC Stock Markets. Accounting and Finance Research, 5(3), 190.

Kingu, P. S., Macha, S., \& Gwahula, R. (2018). Impact of non-performing loans on bank's profitability: Empirical evidence from commercial banks in Tanzania. International Journal of Scientific Research and Management, 6(1), 71-78.

Lipunga, A. M. (2014). Determinants of profitability of listed commercial banks in developing countries: Evidence from Malawi. Research Journal of Finance and Accounting, 5(6), 41-49.

Mamatzakis, E., \& Bermpei, T. (2016). What is the effect of unconventional monetary policy on bank performance?. Journal of International Money and Finance, 67, 239-263.

Menicucci, E., \& Paolucci, G. (2016). The determinants of bank profitability: empirical evidence from European banking sector. Journal of financial reporting and Accounting, 14(1), 86-115.

Molyneux, P., \& Thornton, J. (1992). Determinants of European bank profitability: A note. Journal of banking \& Finance, 16(6), 1173-1178.

Pasiouras, F., \& Kosmidou, K. (2007). Factors influencing the profitability of domestic and foreign commercial banks in the European Union. Research in International Business and Finance, 21(2), 222-237.

Short, B. K. (1979). The relation between commercial bank profit rates and banking concentration in Canada, 
Western Europe, and Japan. Journal of banking \& Finance, 3(3), 209-219.

Usman, B., \& Lestari, H. S. (2019). Determinants of Bank Performance in Indonesia. Jurnal Minds: Manajemen Ide dan Inspirasi, 6(2), 193-204.

World Economic Outlook Databases. Retrieved from World Economic Outlook (imf.org)

Zainuddin, P., Wancik, Z., Rahman, S. A., Hartati, S., \& Rahman, F. (2017). Determinant of Financial Performance on Indonesian Banks Through Return on Assets. International Journal of Applied Business and Economic Research, 15(20), 243-251.

Zopounidis, C., \& Kosmidou, K. (2008). The determinants of banks' profits in Greece during the period of EU financial integration. Managerial Finance, 34(3), 146-159.

\section{Appendix}

Financial Parameters of Listed Banks in the GCC Country-wise - 2018 \& 2019

\begin{tabular}{|c|c|c|c|c|c|c|}
\hline \multicolumn{7}{|c|}{ Bahrain } \\
\hline \multirow[t]{2}{*}{ Banks } & \multicolumn{2}{|c|}{$\begin{array}{c}\text { Total assets } \\
\text { (US\$ million) }\end{array}$} & \multicolumn{2}{|c|}{$\begin{array}{c}\text { Net profit } \\
\text { (US\$ million) }\end{array}$} & \multicolumn{2}{|c|}{$\begin{array}{c}\text { Capital adequacy } \\
\text { ratio }\end{array}$} \\
\hline & 2018 & 2019 & 2018 & 2019 & 2018 & 2019 \\
\hline AUB & $35,507.6$ & $40,280.1$ & 697.5 & 730.5 & $16.9 \%$ & $16.4 \%$ \\
\hline Al Baraka & $23,831.2$ & $26,258.5$ & 129.1 & 105.7 & $17.4 \%$ & $16.7 \%$ \\
\hline Al Salam & $4,548.7$ & $5,420.7$ & 49.2 & 56.1 & $20.6 \%$ & $20.9 \%$ \\
\hline BISB & $3,405.6$ & $3,254.1$ & 30.3 & 16.5 & $17.1 \%$ & $14.8 \%$ \\
\hline BBK & $9,525.8$ & $10,279.3$ & 178.5 & 200.5 & $19.6 \%$ & $21.7 \%$ \\
\hline Ithmaar & $8,488.7$ & $8,085.2$ & -24 & 0.7 & $13.4 \%$ & $13.5 \%$ \\
\hline Khaleeji & $2,263.1$ & $2,499.3$ & 1.8 & -39.7 & $16.2 \%$ & $16.6 \%$ \\
\hline NBB & $8,498.7$ & $8,496.0$ & 186.2 & 197.3 & $33.8 \%$ & $37.3 \%$ \\
\hline Total & $96,069.4$ & $104,573.2$ & $1,248.60$ & $1,267.60$ & $19.4 \%$ & $19.7 \%$ \\
\hline \multicolumn{7}{|c|}{ Kuwait } \\
\hline AUBK & $12,913.1$ & $14,282.4$ & 169.1 & 180.6 & $16.6 \%$ & $16.0 \%$ \\
\hline $\mathrm{ABK}$ & $15,007.6$ & $16,027.5$ & 139.0 & 94.1 & $19.2 \%$ & $18.7 \%$ \\
\hline Boubyan & $14,335.6$ & $17,397.7$ & 185.1 & 205.6 & $18.2 \%$ & $20.3 \%$ \\
\hline Burgan & $24,126.3$ & $23,241.6$ & 272.5 & 277.9 & $17.4 \%$ & $16.8 \%$ \\
\hline GBK & $19,851.0$ & $20,499.0$ & 187.2 & 208.9 & $17.5 \%$ & $17.1 \%$ \\
\hline $\mathrm{KFH}$ & $58,633.2$ & $63,645.5$ & 750.3 & 823.9 & $17.5 \%$ & $17.7 \%$ \\
\hline KIB & $7,155.3$ & $8,821.4$ & 68.9 & 56.3 & $16.6 \%$ & $19.2 \%$ \\
\hline NBK & $90,498.7$ & $96,073.7$ & $1,223.20$ & $1,317.10$ & $17.2 \%$ & $17.8 \%$ \\
\hline CBK & $14,740.7$ & $15,995.1$ & 210.3 & 0.0 & $18.8 \%$ & $18.2 \%$ \\
\hline Warba & $7,240.7$ & $10,318.3$ & 42.0 & 54.3 & $24.3 \%$ & $18.5 \%$ \\
\hline Total & $264,502.20$ & $286,302.20$ & $3,247.6$ & $3,218.7$ & $18.3 \%$ & $18.0 \%$ \\
\hline \multicolumn{7}{|c|}{ Oman } \\
\hline Ahil & $5,949.1$ & $6,541.6$ & 74.8 & 80.6 & $17.5 \%$ & $16.9 \%$ \\
\hline Alizz & $1,773.5$ & $1,867.1$ & 6.2 & -25.9 & $15.3 \%$ & $13.5 \%$ \\
\hline Dhofar & $10,944.1$ & $11,236.0$ & 130.6 & 78.6 & $17.3 \%$ & $17.9 \%$ \\
\hline Muscat & $31,917.0$ & $31,923.7$ & 466.6 & 481.9 & $19.2 \%$ & $19.7 \%$ \\
\hline
\end{tabular}




\begin{tabular}{|c|c|c|c|c|c|c|}
\hline Nizwa & $2,265.4$ & $2,686.7$ & 19.5 & 26.4 & $16.2 \%$ & $14.5 \%$ \\
\hline HSBC & $6,131.5$ & $6,623.4$ & 81.5 & 76.1 & $19.4 \%$ & $18.8 \%$ \\
\hline NBO & $9,280.3$ & $9,466.7$ & 131.4 & 133.6 & $16.3 \%$ & $16.6 \%$ \\
\hline Sohar & $7,912.7$ & $9,104.2$ & 76.3 & 89.4 & $15.0 \%$ & $18.9 \%$ \\
\hline Total & $76,173.6$ & $79,449.4$ & 986.9 & 940.7 & $17.0 \%$ & $17.1 \%$ \\
\hline \multicolumn{7}{|c|}{ Qatar } \\
\hline Ahil & $11,099.7$ & $12,064.5$ & 182.8 & 185.5 & $18.2 \%$ & $18.0 \%$ \\
\hline Al Khaliji & $14,313.9$ & $14,771.4$ & 167.1 & 177.5 & $16.9 \%$ & $19.1 \%$ \\
\hline Doha & $26,410.0$ & $29,727.6$ & 228.1 & 207.1 & $17.0 \%$ & $17.7 \%$ \\
\hline MAR & $26,729.2$ & $29,229.8$ & 585.3 & 598.5 & $19.2 \%$ & $20.3 \%$ \\
\hline QIIB & $13,807.7$ & $15,613.0$ & 242.3 & 254.7 & $16.4 \%$ & $18.5 \%$ \\
\hline QIB & $42,096.8$ & $44,922.9$ & 757.0 & 839.4 & $18.8 \%$ & $19.5 \%$ \\
\hline QNB & $236,867.5$ & $259,532.3$ & $3,787.9$ & $3,942.5$ & $19.0 \%$ & $18.9 \%$ \\
\hline $\mathrm{CB}$ & $37,068.1$ & $40,532.0$ & 459.9 & 555.2 & $15.5 \%$ & $16.4 \%$ \\
\hline Total & $408,392.9$ & $446,393.5$ & $6,410.4$ & $6,6760.4$ & $17.6 \%$ & $18.5 \%$ \\
\hline \multicolumn{7}{|c|}{ Saudi Arabia } \\
\hline Al Rajhi & $97,128.7$ & $102,423.1$ & $1,005.3$ & $2,708.9$ & $20.1 \%$ & $19.9 \%$ \\
\hline Alinma & $32,428.1$ & $35,157.2$ & 762.3 & 675.9 & $21.1 \%$ & $20.3 \%$ \\
\hline ANB & $47,587.7$ & $48,918.0$ & $1,059.0$ & 806.2 & $18.1 \%$ & $18.9 \%$ \\
\hline $\mathrm{BAB}$ & $19,647.2$ & $22,953.4$ & 163.5 & 331.7 & $17.3 \%$ & $17.5 \%$ \\
\hline BAJ & $19,478.3$ & $23,078.5$ & 100.9 & 264.3 & $27.5 \%$ & $24.6 \%$ \\
\hline BSF & $50,761.6$ & $47,506.3$ & 374.3 & 830.7 & $19.8 \%$ & $19.2 \%$ \\
\hline Riyad & $61,340.6$ & $70,877.0$ & 825.1 & $1,493.9$ & $18.1 \%$ & $18.1 \%$ \\
\hline SAMBA & $61,350.9$ & $68,161.0$ & 814.1 & $1,062.5$ & $22.7 \%$ & $21.1 \%$ \\
\hline $\mathrm{NCB}$ & $120,647.4$ & $135,270.3$ & $2,559.8$ & $3,040.4$ & $20.6 \%$ & $18.7 \%$ \\
\hline SABB & $46,606.3$ & $70,792.7$ & 724.5 & 754.8 & $21.3 \%$ & $19.4 \%$ \\
\hline SAIB & $25,632.9$ & $26,883.9$ & 153.7 & 63.9 & $19.4 \%$ & $18.3 \%$ \\
\hline Total & $582,609.7$ & $652,021.4$ & $8,542.5$ & $12,033.2$ & $20.5 \%$ & $19.6 \%$ \\
\hline \multicolumn{7}{|c|}{ UAE } \\
\hline ADCB & $76,174.7$ & $110,284.7$ & $1,317.5$ & $1,303.8$ & $17.3 \%$ & $16.9 \%$ \\
\hline ADIB & $34,080.0$ & $34,295.9$ & 680.6 & 707.8 & $17.2 \%$ & $18.9 \%$ \\
\hline CBD & $20,171.7$ & $23,973.9$ & 316.3 & 381.2 & $14.6 \%$ & $14.2 \%$ \\
\hline DIB & $60,890.2$ & $63,098.8$ & $1,338.3$ & $1,365.0$ & $17.5 \%$ & $16.5 \%$ \\
\hline ENBD & $136,202.0$ & $186,011.7$ & $2,733.2$ & $3,947.9$ & $20.9 \%$ & $18.5 \%$ \\
\hline FAB & $202,498.8$ & $223,753.9$ & $3,269.6$ & $3,408.2$ & $15.7 \%$ & $16.9 \%$ \\
\hline Mashreq & $38,807.6$ & $43,399.9$ & 560.8 & 562.2 & $16.5 \%$ & $16.3 \%$ \\
\hline $\mathrm{NBF}$ & $10,829.7$ & $11,652.3$ & 167.5 & 150.3 & $15.2 \%$ & $17.8 \%$ \\
\hline SIB & $12,180.5$ & $12,628.3$ & 138.9 & 148.5 & $17.7 \%$ & $22.8 \%$ \\
\hline RAK & $14,339.1$ & $15,548.9$ & 248.4 & 298.1 & $17.2 \%$ & $16.8 \%$ \\
\hline Total & $606,174.3$ & $724,648.3$ & $10,771.1$ & $12,273.0$ & $17.0 \%$ & $17.6 \%$ \\
\hline
\end{tabular}


Financial Parameters of Listed Banks in the GCC Country-wise - 2018 \& 2019 (Continuing)

\begin{tabular}{|c|c|c|c|c|c|c|}
\hline \multicolumn{7}{|c|}{ Bahrain } \\
\hline \multirow[t]{2}{*}{ Banks } & \multicolumn{2}{|c|}{ Return on assets } & \multicolumn{2}{|c|}{ Return on equity } & \multicolumn{2}{|c|}{ Cost-to-income ratio } \\
\hline & 2018 & 2019 & 2018 & 2019 & 2018 & 2019 \\
\hline AUB & $2.0 \%$ & $1.9 \%$ & $17.1 \%$ & $17.0 \%$ & $27.1 \%$ & $28.6 \%$ \\
\hline Al Baraka & $0.5 \%$ & $0.4 \%$ & $7.9 \%$ & $6.7 \%$ & $54.7 \%$ & $58.7 \%$ \\
\hline Al Salam & $1.1 \%$ & $1.1 \%$ & $6.1 \%$ & $6.8 \%$ & $48.9 \%$ & $55.6 \%$ \\
\hline BISB & $0.9 \%$ & $0.5 \%$ & $9.5 \%$ & $5.2 \%$ & $53.3 \%$ & $59.3 \%$ \\
\hline BBK & $1.8 \%$ & $2.0 \%$ & $14.6 \%$ & $15.0 \%$ & $36.8 \%$ & $45.7 \%$ \\
\hline Ithmaar & $-0.3 \%$ & $0.0 \%$ & $-10.2 \%$ & $0.6 \%$ & $83.3 \%$ & $75.0 \%$ \\
\hline Khaleeji & $0.1 \%$ & $-1.7 \%$ & $0.6 \%$ & $-16.0 \%$ & $64.3 \%$ & $72.6 \%$ \\
\hline NBB & $2.2 \%$ & $2.3 \%$ & $15.2 \%$ & $14.7 \%$ & $35.6 \%$ & $35.9 \%$ \\
\hline Average & $1.1 \%$ & $0.8 \%$ & $7.6 \%$ & $6.4 \%$ & $50.5 \%$ & $53.9 \%$ \\
\hline \multicolumn{7}{|c|}{ Kuwait } \\
\hline AUBK & $1.4 \%$ & $1.3 \%$ & $12.2 \%$ & $12.4 \%$ & $30.6 \%$ & $37.3 \%$ \\
\hline $\mathrm{ABK}$ & $0.9 \%$ & $0.6 \%$ & $7.3 \%$ & $4.8 \%$ & $38.6 \%$ & $38.9 \%$ \\
\hline Boubyan & $1.3 \%$ & $1.3 \%$ & $14.3 \%$ & $12.7 \%$ & $40.6 \%$ & $41.9 \%$ \\
\hline Burgan & $1.1 \%$ & $1.2 \%$ & $11.6 \%$ & $11.3 \%$ & $42.1 \%$ & $42.1 \%$ \\
\hline GBK & $1.0 \%$ & $1.0 \%$ & $9.2 \%$ & $9.8 \%$ & $34.5 \%$ & $37.6 \%$ \\
\hline KFH & $1.3 \%$ & $1.4 \%$ & $12.1 \%$ & $12.7 \%$ & $39.2 \%$ & $37.4 \%$ \\
\hline KIB & $1.0 \%$ & $0.7 \%$ & $7.8 \%$ & $6.2 \%$ & $53.9 \%$ & $57.7 \%$ \\
\hline NBK & $1.4 \%$ & $1.4 \%$ & $12.0 \%$ & $12.2 \%$ & $31.3 \%$ & $34.0 \%$ \\
\hline CBK & $1.4 \%$ & $0.0 \%$ & $9.2 \%$ & $0.0 \%$ & $29.7 \%$ & $31.6 \%$ \\
\hline Warba & $0.6 \%$ & $0.6 \%$ & $8.6 \%$ & $8.0 \%$ & $38.3 \%$ & $37.5 \%$ \\
\hline Average & $1.2 \%$ & $1.0 \%$ & $10.4 \%$ & $9.0 \%$ & $37.9 \%$ & $39.5 \%$ \\
\hline \multicolumn{7}{|c|}{ Oman } \\
\hline Ahil & $1.3 \%$ & $1.3 \%$ & $11.3 \%$ & $11.9 \%$ & $40.8 \%$ & $43.3 \%$ \\
\hline Alizz & $0.3 \%$ & $-1.4 \%$ & $3.1 \%$ & $-13.4 \%$ & $83.1 \%$ & $88.6 \%$ \\
\hline Dhofar & $1.2 \%$ & $0.7 \%$ & $8.4 \%$ & $5.6 \%$ & $49.6 \%$ & $55.0 \%$ \\
\hline Muscat & $1.5 \%$ & $1.5 \%$ & $10.3 \%$ & $10.1 \%$ & $42.6 \%$ & $41.5 \%$ \\
\hline Nizwa & $1.0 \%$ & $1.1 \%$ & $5.6 \%$ & $7.1 \%$ & $61.5 \%$ & $55.8 \%$ \\
\hline HSBC & $1.3 \%$ & $1.2 \%$ & $9.5 \%$ & $8.5 \%$ & $57.5 \%$ & $56.0 \%$ \\
\hline NBO & $1.4 \%$ & $1.4 \%$ & $9.3 \%$ & $12.0 \%$ & $47.9 \%$ & $49.6 \%$ \\
\hline Sohar & $1.0 \%$ & $1.1 \%$ & $10.1 \%$ & $11.1 \%$ & $42.2 \%$ & $43.3 \%$ \\
\hline Average & $1.1 \%$ & $0.9 \%$ & $8.4 \%$ & $6.6 \%$ & $53.2 \%$ & $54.1 \%$ \\
\hline \multicolumn{7}{|c|}{ Qatar } \\
\hline Ahil & $1.7 \%$ & $1.6 \%$ & $12.3 \%$ & $11.8 \%$ & $28.1 \%$ & $27.3 \%$ \\
\hline Al Khaliji & $1.1 \%$ & $1.2 \%$ & $9.3 \%$ & $10.2 \%$ & $28.8 \%$ & $27.9 \%$ \\
\hline Doha & $0.9 \%$ & $0.7 \%$ & $6.2 \%$ & $5.9 \%$ & $35.5 \%$ & $33.6 \%$ \\
\hline MAR & $2.1 \%$ & $2.1 \%$ & $16.1 \%$ & $16.0 \%$ & $24.0 \%$ & $22.8 \%$ \\
\hline QIIB & $1.8 \%$ & $1.7 \%$ & $15.1 \%$ & $14.7 \%$ & $24.9 \%$ & $24.1 \%$ \\
\hline
\end{tabular}




\begin{tabular}{|c|c|c|c|c|c|c|}
\hline QIB & $1.8 \%$ & $1.9 \%$ & $16.6 \%$ & $17.5 \%$ & $25.4 \%$ & $22.8 \%$ \\
\hline QNB & $1.6 \%$ & $1.6 \%$ & $19.6 \%$ & $19.0 \%$ & $26.6 \%$ & $26.1 \%$ \\
\hline $\mathrm{CB}$ & $1.2 \%$ & $1.4 \%$ & $8.7 \%$ & $10.6 \%$ & $31.8 \%$ & $28.3 \%$ \\
\hline Average & $1.5 \%$ & $1.5 \%$ & $13.0 \%$ & $13.2 \%$ & $28.1 \%$ & $26.6 \%$ \\
\hline \multicolumn{7}{|c|}{ Saudi Arabia } \\
\hline Al Rajhi & $1.1 \%$ & $2.7 \%$ & $7.2 \%$ & $20.4 \%$ & $32.6 \%$ & $32.8 \%$ \\
\hline Alinma & $2.4 \%$ & $2.0 \%$ & $13.7 \%$ & $11.6 \%$ & $38.3 \%$ & $37.1 \%$ \\
\hline ANB & $2.3 \%$ & $1.7 \%$ & $15.6 \%$ & $11.0 \%$ & $34.2 \%$ & $32.7 \%$ \\
\hline $\mathrm{BAB}$ & $0.9 \%$ & $1.6 \%$ & $7.9 \%$ & $14.4 \%$ & $53.1 \%$ & $51.3 \%$ \\
\hline BAJ & $0.5 \%$ & $1.2 \%$ & $3.8 \%$ & $8.7 \%$ & $58.6 \%$ & $57.2 \%$ \\
\hline BSF & $0.7 \%$ & $1.7 \%$ & $4.5 \%$ & $9.8 \%$ & $34.2 \%$ & $33.3 \%$ \\
\hline Riyad & $1.4 \%$ & $2.3 \%$ & $8.2 \%$ & $14.5 \%$ & $37.1 \%$ & $33.8 \%$ \\
\hline SAMBA & $1.3 \%$ & $1.6 \%$ & $7.0 \%$ & $9.1 \%$ & $30.1 \%$ & $33.5 \%$ \\
\hline NCB & $2.1 \%$ & $2.4 \%$ & $16.9 \%$ & $19.1 \%$ & $35.2 \%$ & $30.6 \%$ \\
\hline SABB & $1.5 \%$ & $1.3 \%$ & $8.3 \%$ & $6.4 \%$ & $29.8 \%$ & $38.3 \%$ \\
\hline SAIB & $0.6 \%$ & $0.2 \%$ & $4.6 \%$ & $1.9 \%$ & $40.1 \%$ & $42.5 \%$ \\
\hline Average & $1.4 \%$ & $1.7 \%$ & $8.9 \%$ & $11.5 \%$ & $38.5 \%$ & $38.5 \%$ \\
\hline \multicolumn{7}{|c|}{ UAE } \\
\hline $\mathrm{ADCB}$ & $1.8 \%$ & $1.4 \%$ & $16.3 \%$ & $11.5 \%$ & $33.5 \%$ & $38.5 \%$ \\
\hline ADIB & $2.0 \%$ & $2.1 \%$ & $18.2 \%$ & $16.8 \%$ & $48.6 \%$ & $47.3 \%$ \\
\hline CBD & $1.6 \%$ & $1.7 \%$ & $12.7 \%$ & $14.4 \%$ & $31.5 \%$ & $29.2 \%$ \\
\hline DIB & $2.3 \%$ & $2.2 \%$ & $20.8 \%$ & $18.4 \%$ & $30.1 \%$ & $26.7 \%$ \\
\hline ENBD & $2.1 \%$ & $2.5 \%$ & $18.1 \%$ & $21.8 \%$ & $32.0 \%$ & $32.1 \%$ \\
\hline $\mathrm{FAB}$ & $1.7 \%$ & $1.6 \%$ & $12.7 \%$ & $12.7 \%$ & $27.4 \%$ & $27.2 \%$ \\
\hline Mashreq & $1.6 \%$ & $1.4 \%$ & $10.2 \%$ & $9.9 \%$ & $44.1 \%$ & $43.8 \%$ \\
\hline $\mathrm{NBF}$ & $1.6 \%$ & $1.3 \%$ & $12.8 \%$ & $10.6 \%$ & $33.2 \%$ & $33.0 \%$ \\
\hline SIB & $1.2 \%$ & $1.2 \%$ & $9.4 \%$ & $8.4 \%$ & $52.9 \%$ & $47.7 \%$ \\
\hline RAK & $1.8 \%$ & $2.0 \%$ & $12.2 \%$ & $14.7 \%$ & $38.9 \%$ & $39.5 \%$ \\
\hline Average & $1.8 \%$ & $1.7 \%$ & $14.3 \%$ & $13.9 \%$ & $37.2 \%$ & $36.5 \%$ \\
\hline
\end{tabular}

Source: Compiled from websites of various Central banks in the GCC

\section{Copyrights}

Copyright for this article is retained by the author(s), with first publication rights granted to the journal.

This is an open-access article distributed under the terms and conditions of the Creative Commons Attribution license (http://creativecommons.org/licenses/by/4.0/). 